\title{
A Multidisciplinary Capstone Design Project to Satisfy ABET Student Outcomes
}

\author{
Kala Meah (D), ${ }^{1}$ Donald Hake II, ${ }^{1}$ and Stephen Drew Wilkerson ${ }^{2}$ \\ ${ }^{1}$ Department of Electrical and Computer Engineering and Computer Science, York College of Pennsylvania, York, PA, USA \\ ${ }^{2}$ Department of Civil and Mechanical Engineering, York College of Pennsylvania, York, PA, USA \\ Correspondence should be addressed to Kala Meah; kmeah@ycp.edu
}

Received 27 January 2020; Accepted 24 April 2020; Published 1 June 2020

Academic Editor: Paul S. Szalay

Copyright (c) 2020 Kala Meah et al. This is an open access article distributed under the Creative Commons Attribution License, which permits unrestricted use, distribution, and reproduction in any medium, provided the original work is properly cited.

This paper presents a multidisciplinary open-ended capstone design project where students designed, built, and test drove a Formula Society of Automatic Engineers (FSAE) electric vehicle. The capstone team included students from computer, electrical, and mechanical engineering programs. Each student worked in on a subteam, namely, mechanical design, drivetrain, supervisory control and data acquisition, and battery management system. A thorough description of each subsystem is provided herein. Software architecture, system integration, and field test results are also reviewed. Team organization, faculty and industry involvement, and assessment of student outcomes are provided. This paper details the approach of building a bridge between academia and engineering practices. This paper also documents a process where undergraduate students research and master multiple technology areas and then apply them to the project's focus. ABET student outcomes 1-7 were used to design and assess the course. Peer-to-peer rating and ranking are presented as an assessment tool for the multidisciplinary nature of the project.

\section{Introduction}

The capstone design for electrical engineering (EE), computer engineering (CE), and mechanical engineering (ME) students at the York College of Pennsylvania consists of a two-course sequence in the $6^{\text {th }}$ and $7^{\text {th }}$ academic semesters: Capstone Design I and Capstone Design II. Capstone Design also provides critical improvement to our overall program and ability to assess ABET design and learning criteria [1]. Capstone improves the learning process while preparing undergraduate students for real-world engineering practice. Capstone design is the major design experience in the curriculum and is based on both the knowledge and skills acquired in earlier course work as well as independent research and study. Capstone design projects provide a crucial transition opportunity for students from academic environment to real-world industry-oriented problems [2] and are important and necessary components for student outcome assessment [3]. Capstone design is a training ground where students develop ability to work in a team, apply fundamentals of engineering and sciences, seek new knowledge, analyze an open-ended problem with design alternatives, and create documentations. To support this transition, a capstone design project needs to equip students with skills and knowledge to solve complex and open-ended multidisciplinary engineering problems to address public health, safety, and welfare, as well as global, cultural, social, environmental, and economic factors. This capstone design experience consists of a major interdisciplinary team-based project that includes $\mathrm{EE}, \mathrm{CE}, \mathrm{ME}$, and occasionally computer science (CS) majors. Students are assigned to one project team based on their interest and availability. Projects are typically proposed by the faculty with the students' input.

Students exercise project management skills and use the skills of electrical, computer, and mechanical engineering in an interdisciplinary manner. The same projects may continue for several years allowing for new students to iterate on the prior year's design. Each student on the design team is responsible for a significant engineering design of a component or subsystem. Faculty from computer, electrical, and mechanical engineering, and computer science are assigned to directly support various capstone projects. The faculty role is as a 
mentor or senior advisor, but not as a traditional instructor. The descriptions of the capstone instructor role are mentioned in the previous literature as mentor, facilitator, advisor, and coach but not as an instructor [4-9]. There are no faculty lectures in the capstone project. The students are expected to provide project leadership, establish objectives and deadlines, and report to the faculty in the form of weekly presentations and faculty-established milestones. Therefore, all engineering faculty are "on call" to provide technical support in their specialty area for students who need assistance or resources. This project attribute leads to independent thinking and problem solving on the part of the students $[10,11]$.

ABET guidelines for program curriculum states [12] "Describe the major design experience that prepares students for engineering practice. Describe how this experience is based upon the knowledge and skills acquired in earlier coursework and incorporates appropriate engineering standards and multiple design constraints." The engineering curriculum at the York College of Pennsylvania provides necessary and sufficient scaffolding to prepare students for the capstone design experiences. Table 1 shows the design course sequence for each engineering program, engineering cooperative (coop) work experience, and prerequisites for capstone design. Students complete three mandatory semester-long coop appointments with an industry before they graduate. The first two coops happen before the Capstone Design I, and this helps students to integrate industry experiences into their capstone design projects. The design sequence courses provide laboratory-oriented, project-based, and teamwork experiences. The prerequisite courses prepare students with fundamentals of engineering and science to design, analyze, and experiment complex real-world problems with constraints. Three key elements of an optimal capstone design experience are preparation, administration and execution, and assessment [13]. A part of the preparation is prerequisite knowledge, design experience, and project selection. Engineering programs offer 5-7 capstone design projects each academic year. The capstone instructors send an e-mail to all eligible juniors in the early stage to gauge their interest in capstone design projects. Based on the students' preference and availability, the faculty form the team for each capstone project.

The main objective of this capstone project is to prepare students for the real-world engineering practices. To achieve this objective, the course was designed to bridge the gap between academic knowledge that students acquire through various courses and industry applications. This paper emphasizes on system level integration through effective communication and teamwork. ABET Student Outcomes (SOs) 1-7 [3] are the basis for this capstone design project. This paper presents a detail assessment of each student outcome with examples. ABET SOs are given as follows:

(1) An ability to identify, formulate, and solve complex engineering problems by applying principles of engineering, science, and mathematics

(2) An ability to apply engineering design to produce solutions that meet specified needs with consideration of public health, safety, and welfare, as well as global, cultural, social, environmental, and economic factors

(3) An ability to communicate effectively with a range of audiences

(4) An ability to recognize ethical and professional responsibilities in engineering situations and make informed judgments, which must consider the impact of engineering solutions in global, economic, environmental, and societal contexts

(5) An ability to function effectively on a team whose members together provide leadership, create a collaborative and inclusive environment, establish goals, plan tasks, and meet objectives

(6) An ability to develop and conduct appropriate experimentation, analyze and interpret data, and use engineering judgement to draw conclusions

(7) An ability to acquire and apply new knowledge as needed, using appropriate learning strategies

\section{Course Organization}

The Formula Society of Automotive Engineers (FSAE) electric vehicle team consisted of 11 students: $3 \mathrm{CE}, 3 \mathrm{EE}$, and $5 \mathrm{ME}$. This project had three faculty supervisors: one computer science faculty, one electrical engineering faculty, and one mechanical engineering faculty. The faculty advisor acted as a project manager and provided guidance as appropriate. The faculty advisor did not involve in solving problems. However, faculty advisors help steer the student solution through creative questions. The student outcomes and course objectives were assessed through several tools: daily journals, weekly summaries, weekly standup presentations, milestones, poster presentations, and technical reports. All these documents were available to all team members. Daily journals keep track of student's activities such as any progress, drawings, discussions, and plan. This is not a formal report. This is a reference place where students can find their thoughts and work in progress. Weekly journals summarize their work on the following questions:

(i) What did your team accomplish during the specified timeframe?

(ii) What was your contribution to your team's progress during this time?

(iii) What problems and/or challenges did you encounter during this time and how did you address them?

(iv) What is your plan for the next specified timeframe?

Every week the team meets to provide their progress report as well as the plan for the next week. Each team delivers an update on their accomplishments, challenges, and plans. Milestones are targeted dates for the team to achieve the goals set by the faculty managers. For example, the FSAE electric vehicle team had three milestones in the summer semester and three milestones in the spring semester. Milestone presentation includes each student's 
TABLE 1: Design course sequence, coop, and prerequisites for the capstone design.

\begin{tabular}{|c|c|c|c|c|c|}
\hline $\begin{array}{l}\text { Engineering } \\
\text { program }\end{array}$ & \multicolumn{4}{|c|}{ Design sequence and work experience } & Prerequisites \\
\hline $\begin{array}{l}\text { Electrical } \\
\text { engineering }\end{array}$ & $\begin{array}{l}\text { Engineering practices } \\
\text { and design studios } \\
\text { (semester I) }\end{array}$ & $\begin{array}{l}\text { Introduction to } \\
\text { electrical engineering } \\
\text { (semester II) }\end{array}$ & $\begin{array}{c}\text { Electrical } \\
\text { engineering design } \\
(\text { semester } \mathrm{V})\end{array}$ & $\begin{array}{l}\text { Coop I } \\
\text { and II }\end{array}$ & $\begin{array}{l}\text { Fundamental of computer engineering, } \\
\text { design and analysis of analog circuit, } \\
\text { and introduction to signal processing }\end{array}$ \\
\hline $\begin{array}{l}\text { Computer } \\
\text { engineering }\end{array}$ & $\begin{array}{l}\text { Engineering practices } \\
\text { and design studios } \\
\text { (semester I) }\end{array}$ & $\begin{array}{l}\text { Introduction to } \\
\text { electrical engineering } \\
\text { (semester II) }\end{array}$ & $\begin{array}{c}\text { Software } \\
\text { engineering design } \\
\text { (semester IV) }\end{array}$ & $\begin{array}{l}\text { Coop I } \\
\text { and II }\end{array}$ & $\begin{array}{l}\text { Fundamental of computer engineering, } \\
\text { design and analysis of analog circuit, } \\
\text { introduction to signal processing }\end{array}$ \\
\hline $\begin{array}{l}\text { Mechanical } \\
\text { engineering }\end{array}$ & $\begin{array}{l}\text { Engineering practices } \\
\text { and design studios } \\
\quad \text { (semester I) }\end{array}$ & $\begin{array}{l}\text { Introduction to } \\
\text { mechanical } \\
\text { engineering (semester } \\
\text { II) }\end{array}$ & $\begin{array}{l}\text { Machine design } \\
\text { (semester V) }\end{array}$ & $\begin{array}{l}\text { Coop I } \\
\text { and II }\end{array}$ & $\begin{array}{c}\text { System modeling and analysis, } \\
\text { instrumentation and microprocessor } \\
\text { laboratory, fluid mechanics, machine } \\
\text { design }\end{array}$ \\
\hline
\end{tabular}

completed tasks (hardware, software, and simulation) and plan for the next milestones.

At the end of each semester, the engineering programs invite alumni, industry partners, and community members to the capstone poster presentations and demonstrations. Students prepare for the event to showcase their projects and interact with audiences. The alumni and industry partners provide constructive review and criticism for each project. This is a significant learning opportunity for our seniors.

Each student summarizes his or her design, development, build, and test experiences in a technical report. This document serves as a reference for technical community as well as for the incoming capstone students. The technical report must include the following content: problem/task statement; summary of the design; discussion of engineering changes; design implementation and system integration; critical analysis of the design; lesson learned.

\section{Assessment Process}

The engineering degree programs at the York College of Pennsylvania follow a 3-year cycle for assessing and evaluating all student outcomes. This allowed for a heavier emphasis on careful evaluation of the data in order to identify less severe problems in the program. In addition to this preplanned set of student outcomes targeted for assessment, additional student outcomes were reassessed based on problems that were previously identified and corrective action taken. This ensures that any corrective action will result in a reassessment in order to close the assessment loop and to ensure that the corrective action was effective. Further, if there are any student outcomes for which the assessment data show a potential problem, a targeted assessment of that student outcome will be made in order to gather sufficient data to determine if a problem exists.

For each of the student outcomes 1-7 listed in [3], three to five performance indicators (PIs) were developed to break each student outcome down into measurable constituent components. Each performance indicator addresses a portion of its student outcome. The engineering programs developed rubrics for each performance indicator with three level of expectation such as exceed expectation, meet expectation, and below expectation. Evaluation of the level of attainment of the performance indicators directly supports the evaluation of attainment of the associated student outcome. Performance indicators of student outcome 6 are provided here as an example:

SO 6: an ability to develop and conduct appropriate experimentation, analyze and interpret data, and use engineering judgement to draw conclusions.

PIs:

(i) Designs an experiment

(ii) Conducts an experiment

(iii) Analyzes and interprets data from an experiment

(iv) Uses engineering judgement to draw conclusions from experimental data

A rubric example of PI "design and experiment" is shown in Table 2.

The data collection results are evaluated at the electrical and computer engineering (ECE) retreats. The ECE faculty meet for an all-day assessment retreat each August and January to evaluate the assessment data, discuss areas that indicate problems in student outcomes, and develop a list of action items to make program and process improvements. Action items from the assessment retreats are worked on throughout the year as time and resources permit. In this way, the program undergoes a regular process of data collection, evaluation, corrective action, and reassessment.

3.1. Assessment of Each Subteam. The FSAE electric vehicle team was divided into four subteams: mechanical design; drivetrain; supervisory control and data acquisition (SCADA); battery management system (BMS). Each subteam was responsible to design their subsystem according to the FSAE hybrid rules [14] and to make sure that their subsystem can accommodate/communicate with other subsystems in an effective way to ease the system integration. Following sections provide the assessment of each subsystem. The overall assessment results are discussed later.

3.1.1. Mechanical Design. The mechanical engineering subteam was challenged with the following tasks: design and build the main battery box, battery packs, cooling loop, suspension in rear, steering, drivetrain mount, and cooling 
TABle 2: Rubric for the PI "design and experiment."

\begin{tabular}{|c|c|c|c|}
\hline $\begin{array}{l}\text { Performance } \\
\text { indicator }\end{array}$ & Exceeds expectations & Meets expectations & Below expectations \\
\hline \multirow{3}{*}{$\begin{array}{l}\text { Designs an } \\
\text { experiment }\end{array}$} & $\begin{array}{l}\text { (i) Experiment design, when } \\
\text { correctly conducted, results in } \\
\text { achieving the overarching goals of } \\
\text { the experiment. }\end{array}$ & $\begin{array}{l}\text { (i) Experiment design, when correctly } \\
\text { conducted, results in achieving the } \\
\text { overarching goals of the experiment. }\end{array}$ & $\begin{array}{l}\text { (i) Experiment design, when correctly } \\
\text { conducted, did not achieve the } \\
\text { overarching goals of the experiment. }\end{array}$ \\
\hline & $\begin{array}{l}\text { (ii) Experiment procedure is clear } \\
\text { and concise. Can be performed by a } \\
\text { knowledgeable technician. }\end{array}$ & $\begin{array}{l}\text { (ii) Experiment procedure is mostly } \\
\text { clear and may lack some conciseness. A } \\
\text { technician may have one or two } \\
\text { questions before being able to conduct } \\
\text { the procedure. }\end{array}$ & $\begin{array}{l}\text { (ii) Experimental procedure lacks clarity } \\
\text { and conciseness to an extent that a } \\
\text { technician is unable to perform the } \\
\text { procedure without extensive help. }\end{array}$ \\
\hline & $\begin{array}{l}\text { (iii) Specifies an appropriate amount } \\
\text { of data to be gathered to reach } \\
\text { supportable conclusions. }\end{array}$ & $\begin{array}{l}\text { (iii) Specifies either an appropriate } \\
\text { amount or an excessive amount of data } \\
\text { to be gathered to reach supportable } \\
\text { conclusions. }\end{array}$ & $\begin{array}{l}\text { (iii) Does not specify sufficient data to be } \\
\text { gathered to reach supportable } \\
\text { conclusions. }\end{array}$ \\
\hline
\end{tabular}

system mount. As a starting point for the car chassis, the students made use of the previous FSAE car frame. Typical teams will be assigned tasks in accordance with their own strengths. For example, students with superior CAD skills will typically volunteer for the design work while other students good at machining and building the structure will apply their skill set in the machine shop. In general, using project-based learning (PBL) techniques with mechanical engineers, the students will usually take the path of least resistance. Nonetheless, numerous studies on PBL and its effectiveness can be found in the literature. The value of PBL in mechanical engineering projects has been demonstrated in many applications [15]. The value of PBL in engineering projects involving multidisciplinary applications has been shown in [16-18]. For this particular capstone, students were allowed to do their own research and come up with their own decisions with minimal oversight and guidance. They were given some basic constraints like FSAE hybrid rules, costs, and timelines and were free to formulate their own solutions based on the research.

The team decided on an Emrax 208 motor [19] for its high power density with a universal Unitek Bamocar D3 controller [20]. The motor controller combination can provide a continuous torque of 59 foot-pounds with peak outputs of 118 foot-pounds at the drive shaft. The frame starting point is given in Figure 1. The task for the students was to redesign the rear half of the chassis to accommodate the battery box and drivetrain. The existing frame, motor, and controller along with the battery box and the need for a cooling system are the starting points for the team's effort. A finite element analysis (FEA) of a battery container is shown in Figure 2. Largest stress was observed along the interior wall and was 0.62 kilopound per square inch (ksi). This is below the $8 \mathrm{ksi}$ yield stress of the $1 / 8$-inch aluminum. The team also conducted thermal mapping of the battery cells during the charging and discharging. Figure 3 shows that battery cell temperature did not exceed $70^{\circ} \mathrm{F}$, which is within the recommended safe temperature range. To keep the motor, motor controller, and battery cells cool, a liquid cooling loop is required. The coolant, required by regulation, was water. Analysis for the cooling plates was conducted using Autodesk computational fluid dynamics (CFD). The simulation used a flow rate of 1.2

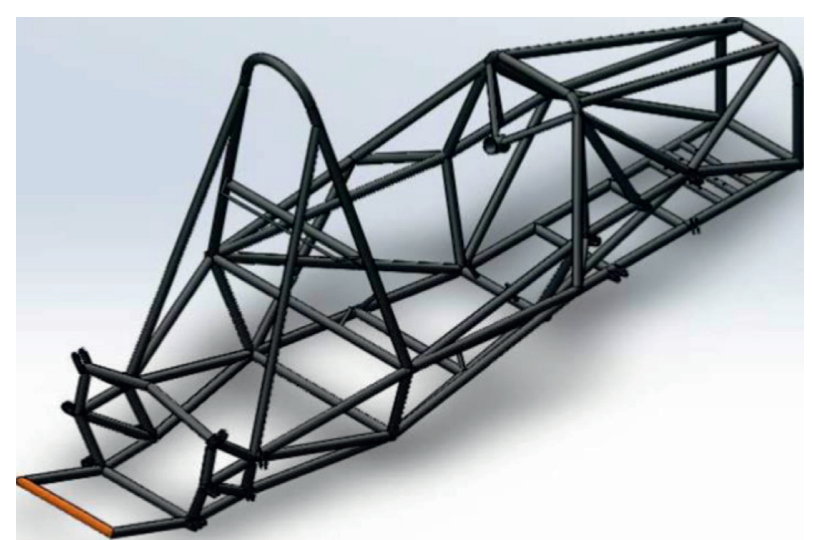

FIgURE 1: Frame from the previous FSAE car.

liters per minute (LPM) (the lowest possible value to be seen by an individual cooling plate). A slight temperature gradient was used to simulate the battery heat generation. The batteries have a tendency to heat more at the top, so a top down gradient was used. The overall outcome was such that the cooling plates individually (under ideal conditions) will support $1.0 \mathrm{~kW}$ of heat transfer in the current scenario which satisfies the design requirements.

A chain drive was used to transmit the torque from the motor shaft to the wheel. It was determined that a limited slip differential would allow the wheels to spin at different rates when entering a turn and provide an advantage. A limited slip differential has the ability to still transmit the torque to both wheels when there is a sudden change in torque. These modifications also needed to adhere to FSAE rules and size constraints. The solution the students came up with is summarized in Figure 4 . The team designed and conducted FEA on the motor mount. Figure 5 shows FEA for the right motor mount with a minimum factor of safety of 10.1. Mechanical engineering students used the knowledge and skills from system modeling and analysis, fluid mechanics, machine design, and coop to design, build, and test the frame, mechanical parts of the drivetrain, thermal systems, and battery housing.

During the Capstone Design I period, the assessment was concentrated on SOs 1,6 , and 7 . The team was presented 


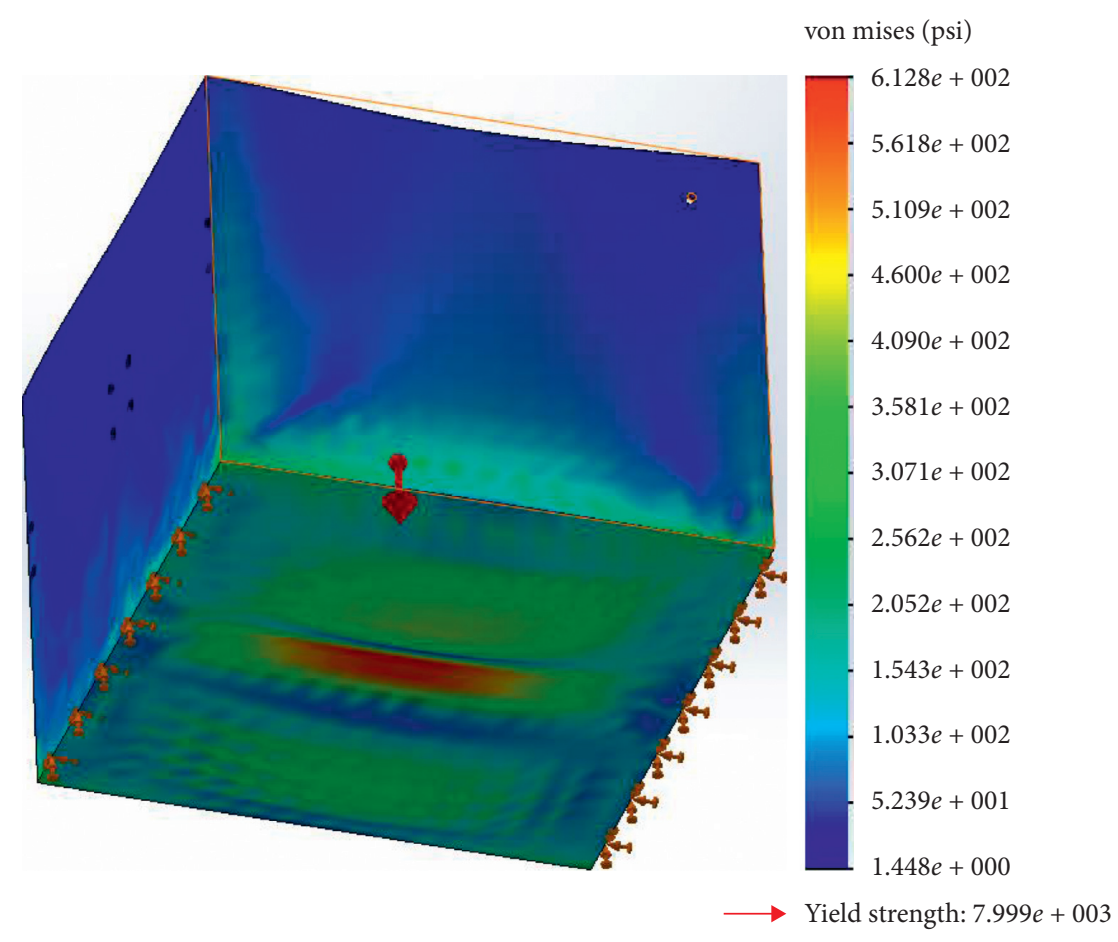

Figure 2: Finite element analysis (FEA) of the battery container.

with an open-ended complex problem to design, build, and test a mechanical structure for the FSAE electric car. To identify and formulate the problem, students used the knowledge from previous courses as well as acquired and applied new knowledge through independent research. The students used available software and hardware resources to develop and conduct appropriate experimentation and analyze and interpret data. Each student provided conclusions using engineering judgement based on their prototype testing. Program level rubrics were used to assess each student's work as shown in Table 2.

Capstone Design II focused on SOs 2 and 3. Each student in the mechanical design team had to pay attention to the safety factor during the building and testing by comparing the results with the analysis. Environmental and economic factors were assessed by using a metric that emphasized the optimization of cost and the minimization of the environmental impacts. It was crucial to communicate with the team members as well as with other teams during the building phase to make sure that the mechanical structure had the accommodation for battery box, drivetrain, SCADA, cooling systems, and wiring. Assessment of student outcomes 4 and 5 was addressed holistically for all design teams.

3.1.2. Drivetrain. The drivetrain uses the Unitek Bamocar D3 motor controller to apply power to the motor from the DC voltage source and the batteries and properly ensure safety of the motor controller. The motor controller also converts DC to a three-phase AC before the power goes to the motor. The drivetrain consisted of multiple subsystems. These included the accumulator isolation relays
(AIRs), the tractive system control board (TSCB), the precharge circuit, the discharge circuit, the motor controller, and the motor. The AIRs were responsible for allowing the flow of the high voltage to be controlled. There is a total of three relays included in the final design to cover the connection of high voltage negative, a resistive path to high voltage positive, and a nonresistive path to high voltage positive. The precharge circuit accomplished the task of applying high voltage to the motor controller by decreasing the in-rush current. This circuit was designed based on the specifications by Unitek [20], the company that makes the motor controller. The discharge circuit accomplished the task of discharging the controller to under $60 \mathrm{~V}$ in under five seconds based on the FSAE rules after including $100 \mathrm{k} \Omega$ resistors across the two timing circuit capacitors.

The specifications used to design the system were provided by SAE in the Formula Hybrid SAE rules [14]. The drivetrain subteam designed and fabricated a TSC to meet the requirements. Figure 6 shows the overall operation and communication of the drivetrain subsystem. The heart of the drivetrain subsystem is the custom-designed TSCB [21]. The FSAE requires that the high-voltage system be controlled by a nonprogrammable logic in order to increase the safety of the high-voltage system. The TSCB uses the digital logic to engage and disengage the high-voltage system and the motor controller inputs. Nonprogrammable combinational logic circuits are widely used for the vehicle tractive systems for their reliability in detecting failures to ensure safe operations [22-27].

Students used circuit simulation tools to design, analyze, and test the circuit before they implemented it using a breadboard. After the successful breadboard testing, the 

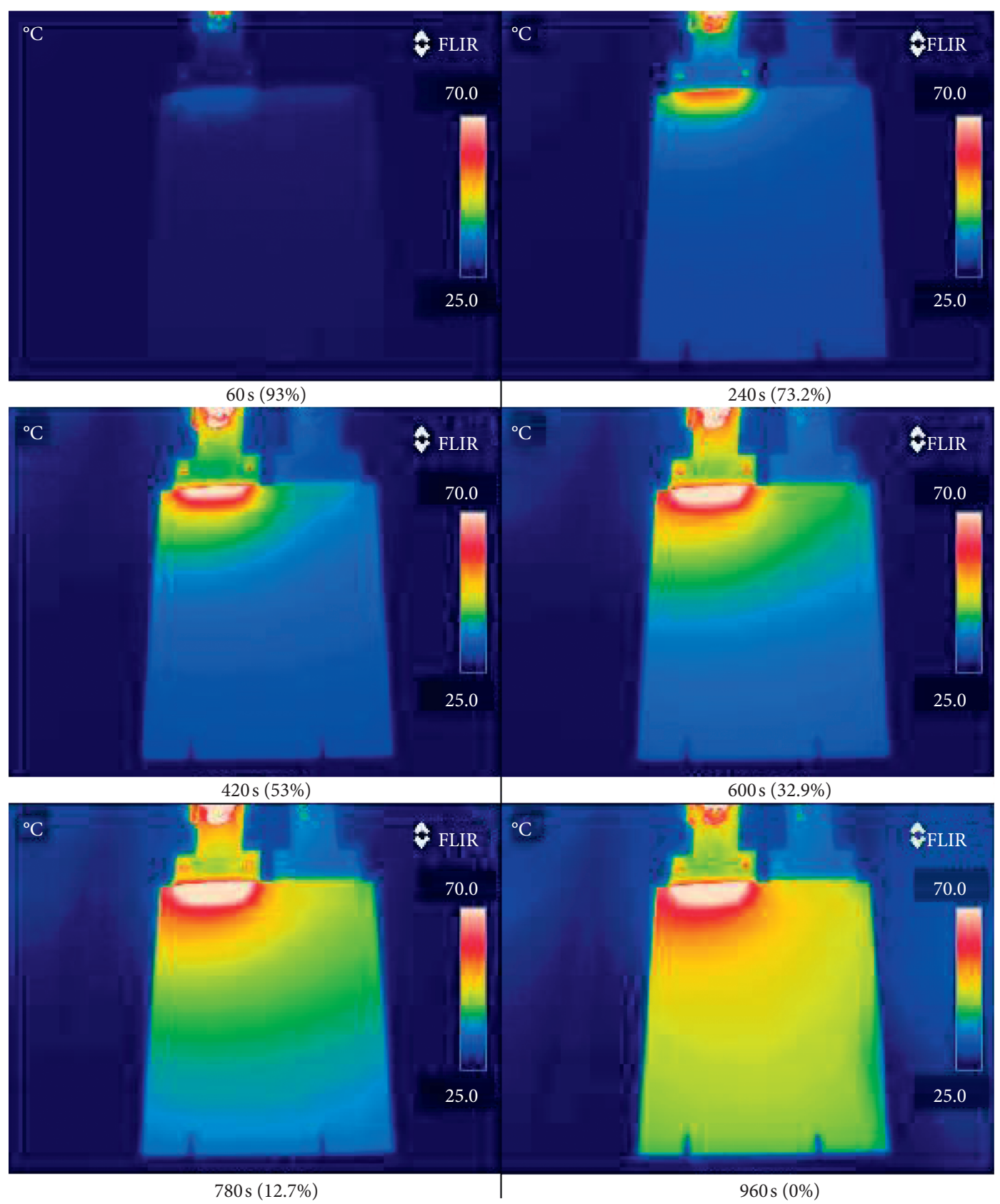

FIGURE 3: Thermal mapping of the battery cells.

team designed a printed circuit board (PCB) using the available software tools. The PCB design and hardware implementation of the nonprogrammable TSCB along with SCADA interface and other subsystems interface can be seen in Figure 7. The electromechanical components of the drivetrain can be seen in Figure 4(a). During the design and analysis process, students used their engineering and science knowledge to integrate electrical and electronics components to develop the complex TSCB. The team had to pay careful attention to interface and information processing to maintain the safety of the vehicle. The drivetrain team gained comprehensive experiences in electronic design and implementation along with the electromechanical interface.
The drivetrain team used the Formula Hybrid SAE rules as constraints to identify, formulate, and solve a complex engineering problem that resulted in a custom tractive system control board (TSCB). In doing so, students used knowledge from previous analog and digital courses. Students also acquire and apply new knowledge such as learning about PCB design, simulation, and component selection. During the circuit building and component selection, they had to pay attention to cost, safety, and environmental impact. As the central system of the drivetrain, the TSCB communicates with SCADA, BMS, grounded low voltage (GLV), motor controller, and AIR. The team designed and conducted appropriate experimentation to analyze and interpret data. The team used engineering judgement to 


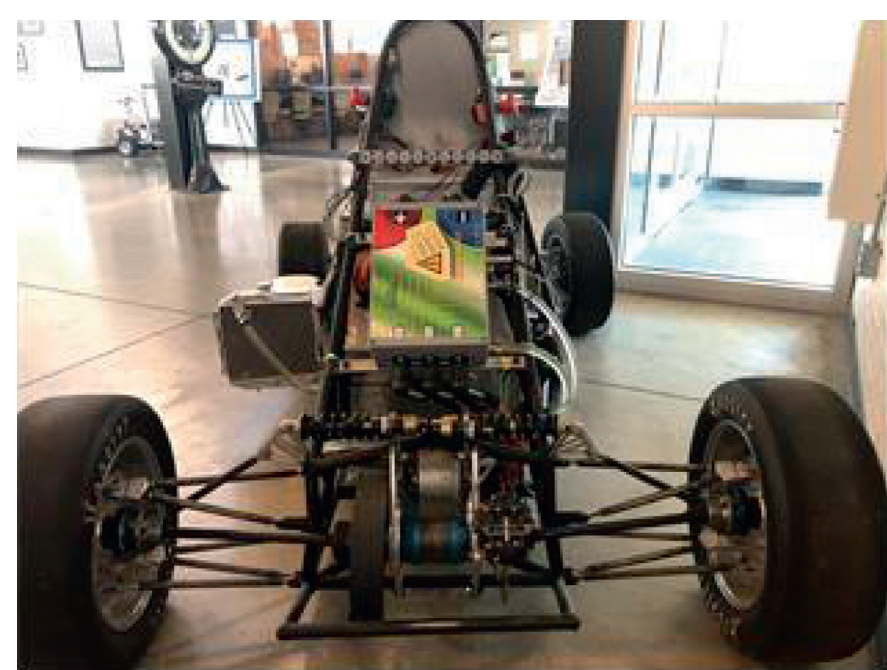

(a)

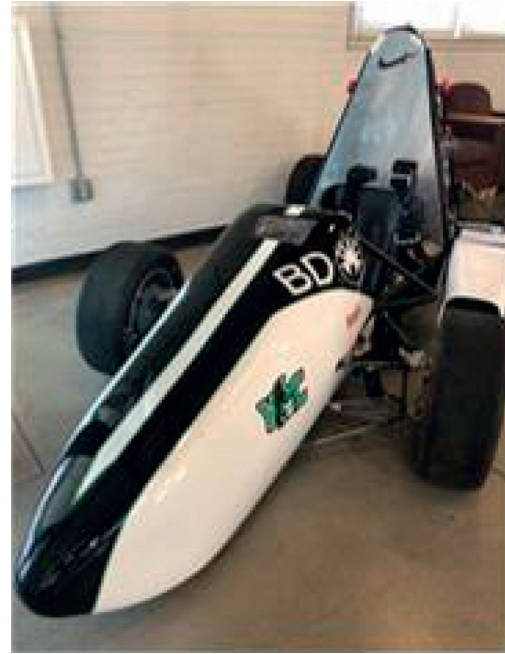

(b)

Figure 4: (a) Back modifications for the drivetrain and battery box and (b) front modification for the SCADA system and dashboard.

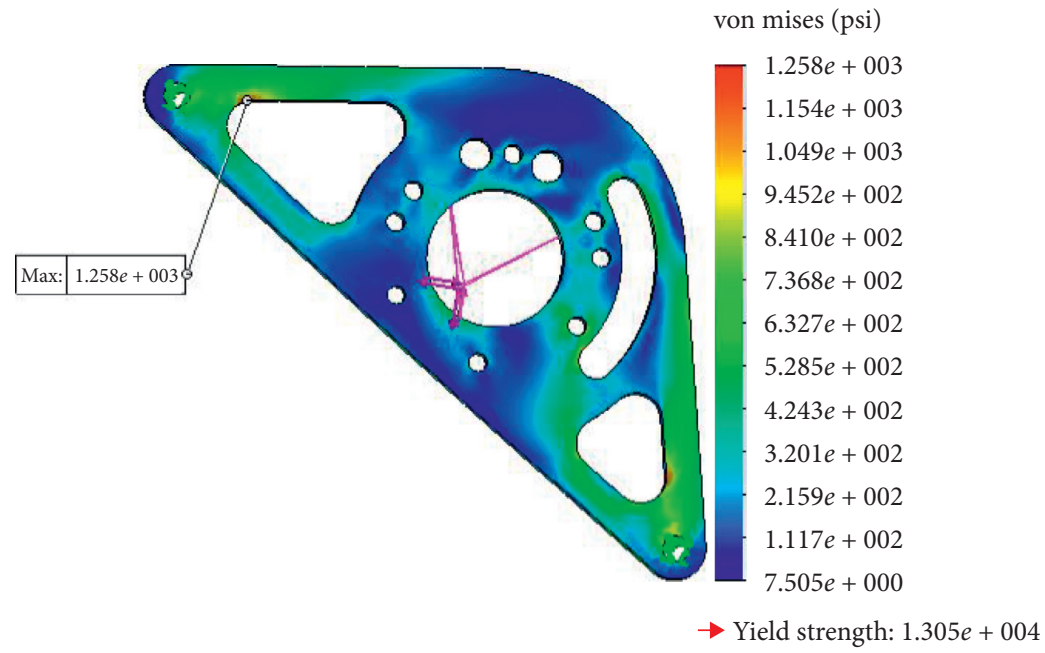

FIGURE 5: FEA for the right motor mount with a minimum factor of safety of 10.1 .

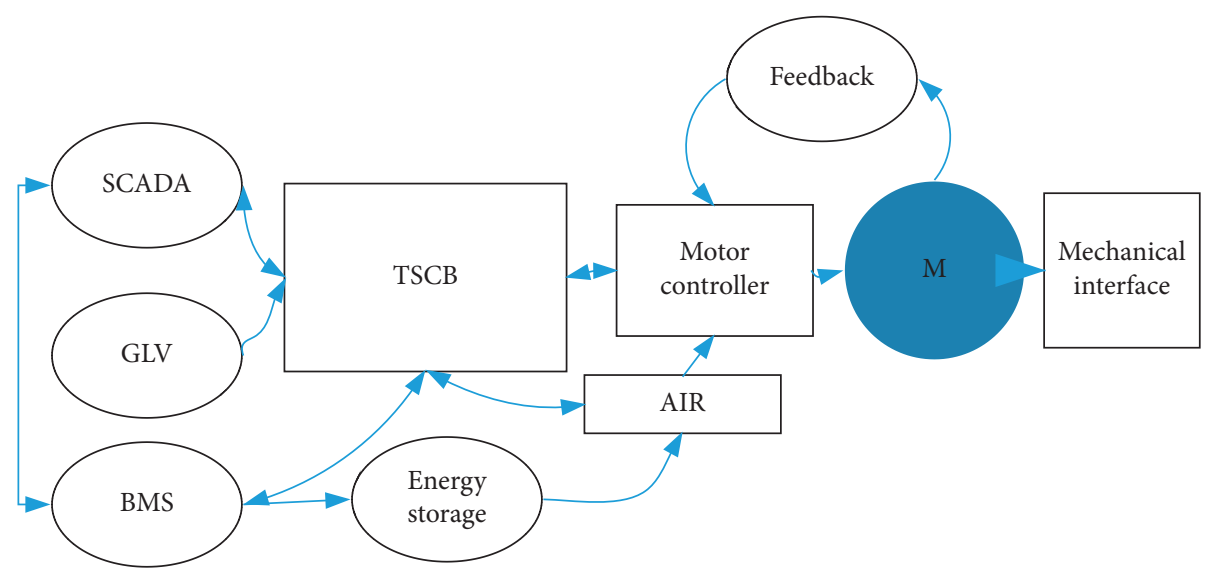

FIGURE 6: Overall operation and communication of the drivetrain subsystem. 


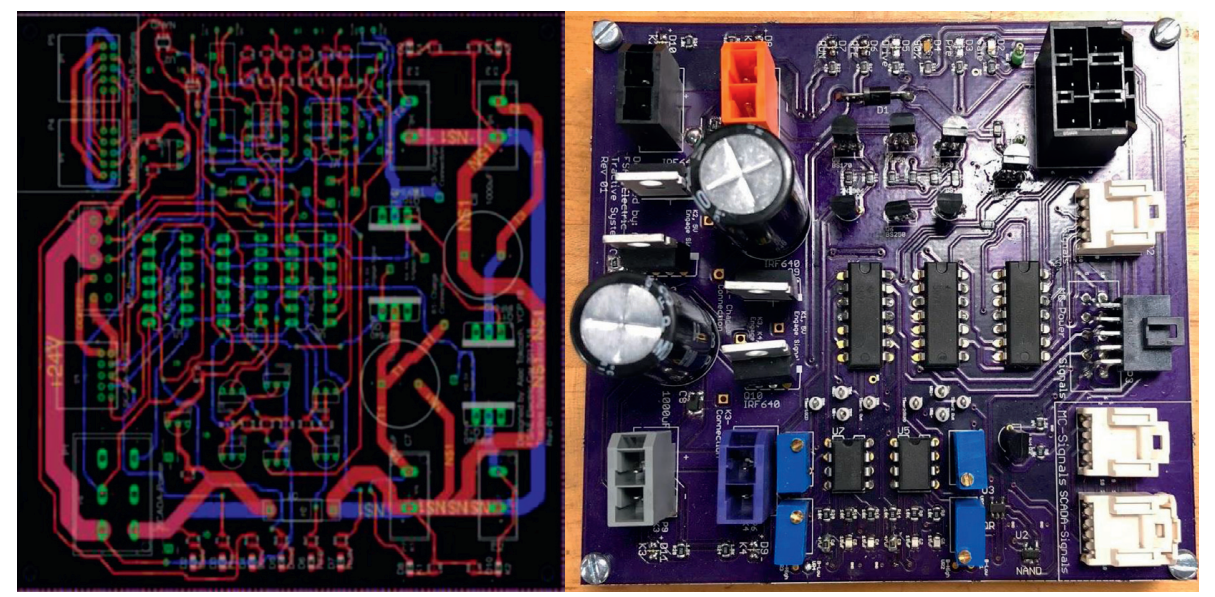

Figure 7: The final PCB design and actual hardware of the TSCB.

finalize and/or redesign the circuit to ensure the safety and security of the operation. Drivetrain is the place where mechanical design meets electrical systems. Effective communication between all design teams was the key for a successful system integration. Appropriate program level rubrics were used to assess SOs 1, 2, 3, 6, and 7 .

\subsubsection{Supervisory Control and Data Acquisition (SCADA).} The objectives for the SCADA team were to design and implement the software architecture to handle events for the real-time operation and the main brain hardware. The team researched how to lay out the structure of the code base, the flow of code, implementation, integration, and testing on the target device. The team established the tools and libraries to use during the development so that any issues can be sorted out ahead of when the rest of the development team starts work.

The SCADA system interacts with the tractive system control board (TSCB) and the battery management system (BMS) as shown in Figure 6 to control the actions of the vehicle such as control the motor, high-voltage and low-voltage systems safety, and static data storage system. The communication protocol and system design were guided by the FSAE formula hybrid electric vehicle rules book [14]. The motor controller directly controls the motor speeds through a speed command from the SCADA via TSCB. Due to this important aspect, significant consideration was given to the motor controller while selecting the protocol and interface of the SCADA system. After extensive research and testing, the controller area network (CAN) bus, a two-wire differential voltage communication protocol, was selected $[28,29]$ due to its robustness.

The heart of the SCADA hardware system is a microcontroller. The team researched and compared various microcontrollers as shown in Table 3 to the suitable one. The team decided on Teensy 3.6 for its microSD slot, real-time clock, and floating point coprocessor [30]. Figure 8 shows logical connections of hardware for the Teensy 3.6. The CAN bus is connected to Teensy through an MCP2562 transceiver module [31].

The team researched published articles on simulation and/or implementation of a SCADA system for an electric vehicle to design their own system [32-36]. The team designed the main brain hardware around the Teensy microcontroller that controls the action of the following hardware to maintain safety at all time:

(i) A brake over-travel (BOT) switch

(ii) Tractive system master switch (TSMS)

(iii) Grounded low-voltage master switch (GLVMS)

(iv) Two side-mounted big red buttons (BRBs)

(v) Insulation monitoring device (IMD) interlock

(vi) Cockpit-mounted shutdown button

(vii) Accumulator management system interlock

(viii) Two accumulator isolation relays (AIRs) as the primary means of engaging and disengaging the tractive system (TS) voltage

The team designed the circuit to satisfy FSAE rules and tested the design using circuit simulation software. After the successful simulation, the team tested the hardware on breadboards. During the hardware testing, the IMD/BMS interface circuit experiences bouncing during the relay operation. This issue was resolved by adding a $47 \mu \mathrm{F}$ filter capacitor across the $5 \mathrm{~V}$ rail of the IMD/BMS circuit and by placing $100 \mathrm{nF}$ bypass capacitors close to the power pins of every IC on the board. After the comprehensive simulation testing and breadboard hardware testing with all peripheral subsystems, the final PCB of the SCADA system was built as shown in Figure 9. This board shows all the input and output signals and as well as the power connections.

The team designed and implemented an electric vehicle operating system (EVOS) using a model view controller (MVC) $[37,38]$ to work with the SCADA hardware described above. To implement the software architecture, the team designed a unified modeling language (UML), finite state diagram, and software flow. A simplified diagram of the MVC is shown in Figure 10. After working out the architecture of EVOS, a feature-rich development environment was desired over the default Arduino editor to assist with the design implementation. The solution found was PlatformIO [39], with features such as code breakpoints, built-in library manager/updater, and its integration with the visual studio 
TABLE 3: Decision matrix of the microcontroller selection.

\begin{tabular}{|c|c|c|c|c|c|}
\hline \multirow{3}{*}{$\begin{array}{l}\text { Family of chips } \\
\text { Features MCU model: } \\
\text { Processor }\end{array}$} & \multicolumn{2}{|c|}{ Arduino } & \multicolumn{3}{|c|}{ Teensy } \\
\hline & Uno & Mega & 3.2 & 3.5 & 3.6 \\
\hline & ATmega328P & ATmega2560 & Cortex-M4 & Cortex-M4F & Cortex-M4F \\
\hline Clock speed $(\mathrm{MHz})$ & \multicolumn{2}{|l|}{ 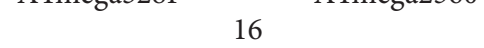 } & 72 & 120 & 180 \\
\hline Instruction size (bits) & \multicolumn{2}{|c|}{8} & & 32 & \\
\hline Estimated MIPS & \multicolumn{2}{|c|}{16} & 90 & 150 & 320 \\
\hline RAM (KB) & 2 & 8 & 64 & 192 & 256 \\
\hline Flash size $(\mathrm{KB})$ & 32 & 256 & 256 & 512 & 1024 \\
\hline EEPROM (KB) & 1 & 4 & 2 & & \\
\hline Operating voltage $(\mathrm{V})$ & \multicolumn{2}{|c|}{$7-12$} & \multicolumn{3}{|c|}{$3.6-6$} \\
\hline CAN bus (\# of ports) & \multicolumn{2}{|c|}{0} & 1 & 1 & 2 \\
\hline Interrupt enabled pins & 2 & 6 & 34 & \multicolumn{2}{|c|}{58} \\
\hline Extras & $\begin{array}{c}\text { Removable } \\
\text { ATmega328P }\end{array}$ & & RTC slot & \multicolumn{2}{|c|}{ MicroSD card slot, built in RTC } \\
\hline Cost (USD) & $\$ 11$ & $\$ 35$ & $\$ 20$ & $\$ 25$ & $\$ 30$ \\
\hline
\end{tabular}

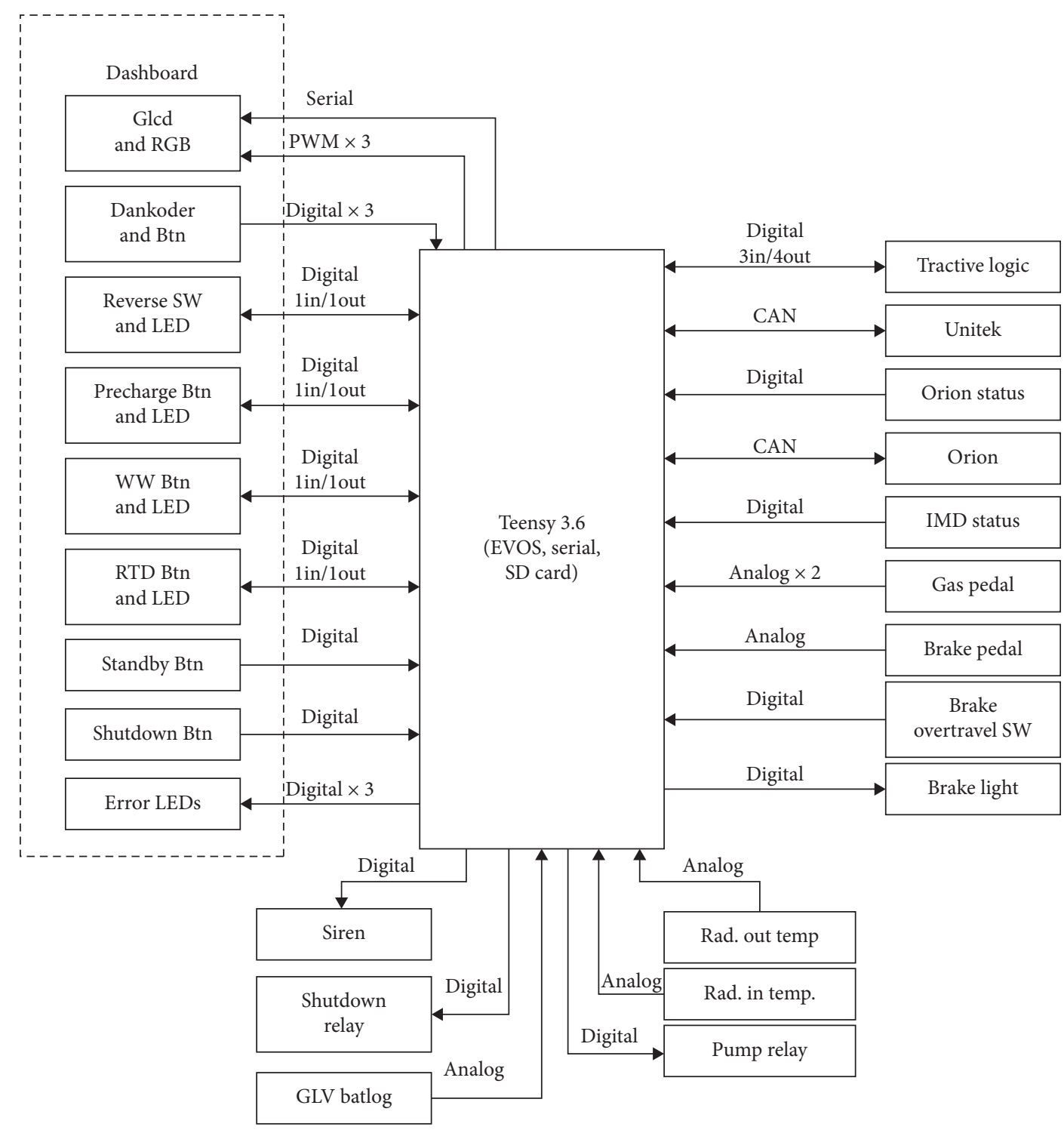

FIgURE 8: Logical connections of hardware for Teensy 3.6. 


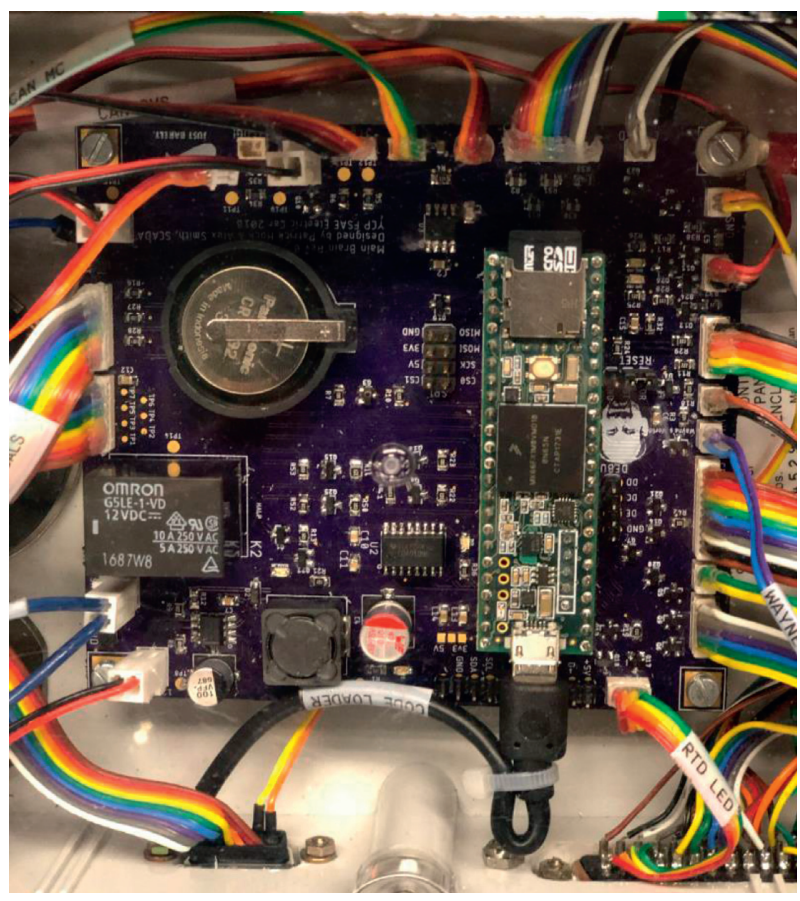

FIgURE 9: SCADA main brain.

code (VSCode) editor [40] which made it an obvious choice. In addition to the features of PlatformIO, using VSCode allowed for access to its expansive marketplace for extensions.

Agile development practices [41, 42] were followed during the software development and integration. In order to verify, the development team stayed updated on what is happening in EVOS, and the team organized scrum meetings. These occurred on a bidaily basis where each member gave a short 2-3 minute status update about what they did, what they plan to do, and what is stopping them. This also became effective in determining who on the team was putting the effort forth towards the issues assigned to them. These issues represented features/bugs of EVOS, and each one was given a priority level (critical, high, medium, and low) and a duration estimate (small (1-2 days), medium (3-5 days), and large (1 week)). The issues would then be distributed to people on the development team based on how many issues they completed the previous sprint. The development process throughout the semester was broken up into one weeklong sprints. Each sprint required a sprint planning meeting where everyone gave their input about what went well and what issues should be completed during the upcoming sprint.

The SCADA team researched the solution to develop the main brain hardware and the algorithm to process the information and control the action of the car. The design team went through a systematic approach to identify the component, formulate circuit, and design and build the functional main brain hardware. The team members also developed their own electric vehicle operating system (EVOS). Each subsystem of the SCADA hardware was tested separately with the appropriate experimental setup. Students learned about PCB software and simulation, model view controller architecture, and agile development practices. They applied these new knowledge to design and build the SCADA system that communicates with all crucial subsystems of the car to maintain a safe operation. During the process, SOs 1, 2, 3, 6, and 7 were assessed with appropriate program level rubrics.

3.1.4. Battery Management System (BMS). Formula SAE hybrid car guidelines were followed to design and build the battery management system (BMS) [14]. The battery had to be less than or equal to $300 \mathrm{~V}$ with a max of $120 \mathrm{~V}$ per segment, and the max energy storage for each segment had to be less than $6 \mathrm{MJ}$. The BMS must constantly monitor all cell voltages, must monitor $30 \%$ of cell temperatures, must shut entire car down, and must only be able to be resettable manually during fault condition, and all voltage sense wires must be protected by fuses. To satisfy the requirements, each of the segment packs for the battery is made of 30 A123 AHP14 Prismatic pouch cells all connected in series. The A123 AHP14 batteries are $3.3 \mathrm{~V}$ each with a $14 \mathrm{Ah}$ capacity. Each of the segment packs is nominally $100 \mathrm{~V}$ when charged. The entire battery is made of three segment packs connected in series to total $300 \mathrm{~V}$. The maximum energy storage was $5.44 \mathrm{MJ}$.

The battery pack is constructed with heat sink plates lined with sheets of compressible silicon foam in between each set of two batteries. These filler materials are required by the hybrid rules. The batteries are held together by end plates putting pressure on each cell with 4 aluminum rods, one in each corner of the plate, pulling the cells together. The requirement for pressure is to allow $8 \%-12 \%$ expansion of 


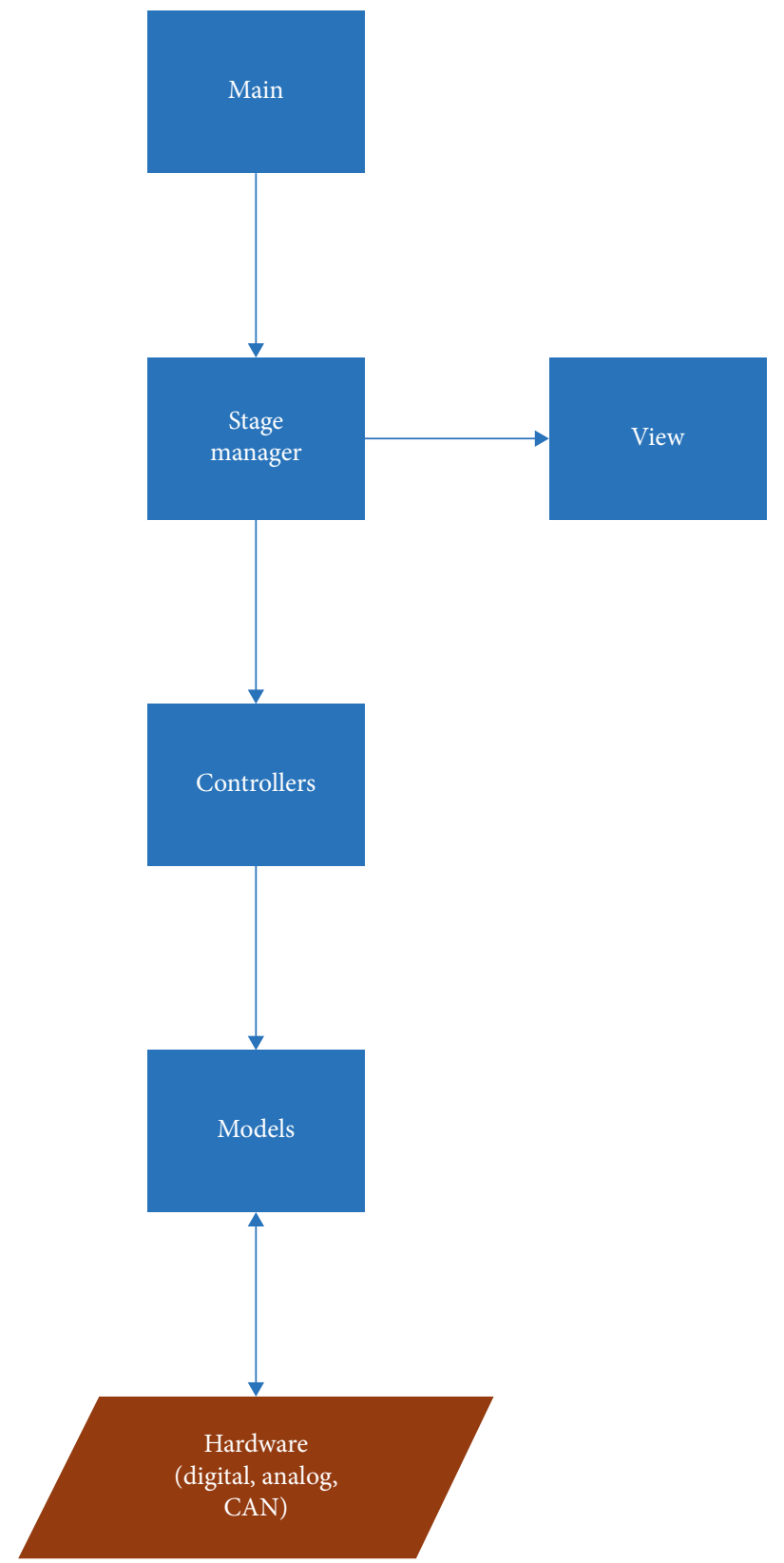

Figure 10: A simplified diagram of the MVC.

the cells before the pressure reaches 10 psi, specified in the FSAE rules. The cell tabs are then separated with a piece of high-density foam, and aluminum wedges are placed into each of the slots in the foam piece. On these wedges are the voltage sense lines and the thermistor lines that route up through another foam piece that is laid on top of the foam piece with the aluminum wedges. A PCB is then put on top of this piece of foam, and all of the voltage sense and thermistor connections are soldered to the PCB. The PCB has lines that route to 3 connectors. One of the connectors is the voltage sense connector. The second and third connectors are for positive and negative for the thermistors. All of these connections go to the BMS for monitoring the battery pack. Figure 11 shows the battery pack without the box and insulation materials.
The Orion battery management system is used in the electric vehicle [43]. The battery management system monitors several parts of the battery pack. Some examples of the monitoring done by this BMS are the individual cell voltages, the total pack voltage, the temperatures of the cells, the state of charge of the pack, the state of health of the pack, the output current, and the limits on current for both input (charging) and output (powering the motor controller to spin the motor). The Orion BMS also monitors for errors in the battery pack. If an error is detected, it triggers an error line and then sets off the safety circuit. When the safety circuit is triggered, the high-voltage tractive system is shut off. The Orion BMS has two CAN connections with programmable baud rates. CAN1 is running at $250 \mathrm{kbps}$ for the charger and thermistor expansion module, and CAN2 is 


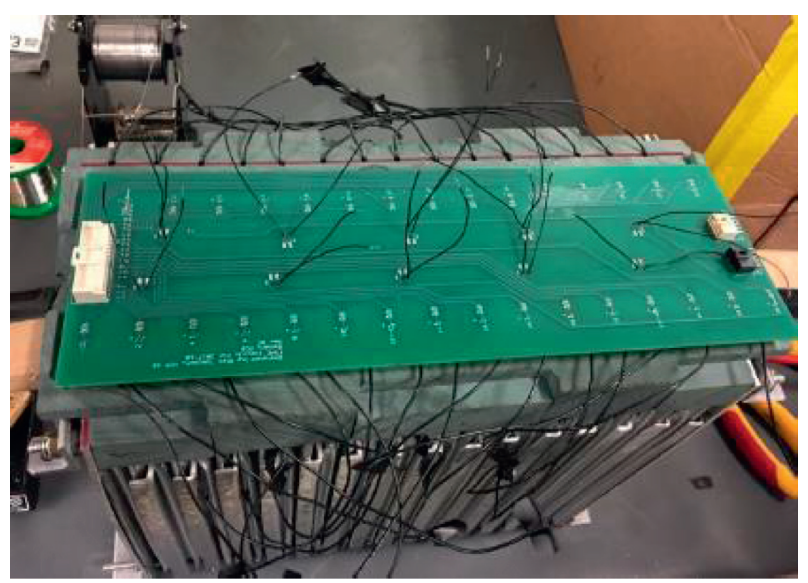

FIGURE 11: Battery pack without the box and insulation materials.

running at $500 \mathrm{kbps}$ for communication with the main brain. The CAN2 network also contains the motor controller traffic. The messages are set up with either 1 byte or 2 byte of data per value. For example, ID $0 \times 420$ : first byte, state of charge; second byte, state of health; third byte, highest temperature; fourth byte, average temperature; fifth and sixth bytes, max open-cell voltage; and seventh and eighth bytes, low open-cell voltage. For ID $0 \times 421$ : first and second bytes, pack discharge current limit of the pack; third and fourth bytes, pack summed voltage; fifth and sixth bytes, pack current; and seventh and eighth bytes, average opencell voltage.

To ensure a safe operation, the BMS team custom designed a battery cell monitoring system and integrated it into the electric vehicle. This subteam worked closely with the SCADA and mechanical design subteam during the design and implementation process. Team members learned the importance of interdisciplinary communication skills and teamwork. The design and implementation work of this team was appropriate to assess SOs 1, 2, 3, 6, and 7.

\section{System Integration}

The system integration started with the mechanical structures that include the modified frame to accommodate the drivetrain, SCADA system, battery management system, grounded low-voltage system, and cooling system. During the testing and integration, the communication between subteams was very crucial. The final assembly of putting all of the pieces together was the most difficult due to the space constraints. The team had to make sure the operation of the vehicle without sacrificing safety of the system and integrity of the design. The mechanical team installed differential, motor, drive-chain, brakes, and chain guard in the rear. The mechanical team also made the housing for the battery and its cooling system. The drivetrain team started working on DC high-voltage wiring to the motor controller and discharge box, AIRs' connection, and three-phase high-voltage wiring. The tractive system control board (TSCB) was the most important integration element of the drivetrain because it is what enables high voltage, the inputs to the motor controller, and disengages them as well in all circumstances. The TSCB was mounted in the low-voltage section of the battery box. The motor controller was mounted onto the frame such that there was enough room below it to account for the routing of the high-voltage wiring. All information including the wiring diagram of the drivetrain system were saved on the common share drive.

The SCADA system integration process for EVOS involved incremental steps with the hardware. These steps include working with the main brain $\mathrm{PCB}$, laying out the dashboard, and building the GLV power distribution board. The main brain was tested with one subsystem at a time to verify the functionality and compatibility. The dashboard was custom built to provide the driver with the vehicle status. The GLV system was designed and assembled to supply power to the BMS, cooling pump, fan, main brain, TSCB, and motor controller. With the intensive communication between subteams and the meticulous assembly and testing, the vehicle came together as shown in Figure 4 .

4.1. Laboratory and Field Test. The team designed and built a table to test the vehicle in the laboratory. The wheels can rotate freely while the vehicle is on the table. The team developed a manual to start and stop the vehicle safely. This manual includes the instructions for battery charging, GLV operation, high-voltage operation, safety circuit descriptions, engaging and disengaging drivetrain, and SCADA system monitoring. The step-by-step procedures helped the team to test the vehicle several times in the laboratory. During the testing, the SCADA team found an issue with the interruption by crosstalk noise. An appropriate filter was designed to resolve the issue. To fix bugs in the SCADA software, a logging system was designed and implemented to record critical events and data as EVOS ran. The logs were CSV based to allow for ease of importing into programs such as NeoOffice, Google Sheets, and Excel. During testing, this allowed to more accurately determine what was occurring and verify that the system was performing correctly.

The drivetrain team noticed that the relays (AIRs) that were connected in parallel to $1000 \mu \mathrm{F}$ capacitors were not engaging correctly. They would "chatter"-rapidly engage and disengage while the capacitor charged, and once the capacitor is charged, the relay would completely engage. This was unwanted behavior of the relay, and it was due to the capacitors drawing more current to charge so the relay was unable to fully engage in the right away. To fix this issue, the TSCB was modified in three locations to add diodes and resistors. The TSCB also needed to be modified to include $100 \mathrm{k} \Omega$ resistors across the two timing circuit capacitors. These were required to discharge the capacitors within seconds of losing $+5 \mathrm{~V}$ on the capacitors so that the timer could be used relatively soon if the car went to standby and then was precharged moments later.

The design team was satisfied with the laboratory test results and ready to conduct the test drive. The team took the vehicle to an empty parking of the college with appropriate safety measures. The vehicle completed several rounds in a parking lot while team members took their turns in driving. 
The vehicle accelerated to 25 kilometers/hour without any problem. Figure 12 shows the vehicle during a field test driving. An optimal capstone experience stretches the students' body and mind to their limits in a voluntary effort to accomplish something difficult and worthwhile [13]. This project provided that experience to the students.

4.2. Overall Student Outcome Assessment. In order to assess the student outcomes, the capstone team was challenged with an open-ended problem to design, test, build, and test drive an FSAE electric vehicle. The team successfully accomplished the goal within the constraints given by the Formula Hybrid SAE. In doing so, each student in the team did independent research to bring the ideas to identify, formulate, and solve the complex problem in hand. The team spent half of the Capstone I semester on research and complex problem aspects of the project. The team then designed experimental procedures and setup to test each subsystem, collect data, and draw conclusion in real time. Data and conclusion were validated by the research and theory. Capstone II is dedicated to the integration and testing. During this period of the time, students not only try to perfect their own design but also built interfaces with other subsystems through mechanical connections, electrical connections, and software signals. This is a very crucial step for the team where they need to understand the complete project as a system. Each student need to pay detail attention to safety because each prototype has its own mechanical, electrical, and software requirements and they need to work in synchronization with other subsystems. Communication was a key factor throughout the process and plays a vital role during the system integration. The instructors used every opportunity to enforce the importance of communication, such as in weekly meetings, milestone presentations, agile development process, and weekly group meetings. Student outcome 5 was assessed through the instructors' direct observation that included the following components: contributes to meet the team objectives; participates in establishing goals and task planning; participates within an organizational structure and process to create an inclusive environment; fosters collaborative team environment.

Students were responsible to select and order parts/ components for the project. They had to research and present options based on safety, environmental, and economic factors. All orders need the approval from the instructor. Ethical and professional responsibilities were enforced in all communications, meetings, and presentations. The students understand the IEEE Code of Ethics and other ethical and professional responsibilities of an engineer and the consequences of unethical and unprofessional behavior. Each student was required to write a technical report to summarize their semester long work. Some components of student outcomes were assessed holistically through the technical report. Each student was asked to address the following in their technical report:

(i) Provide detail description of the standards used in the design and implementation of the project

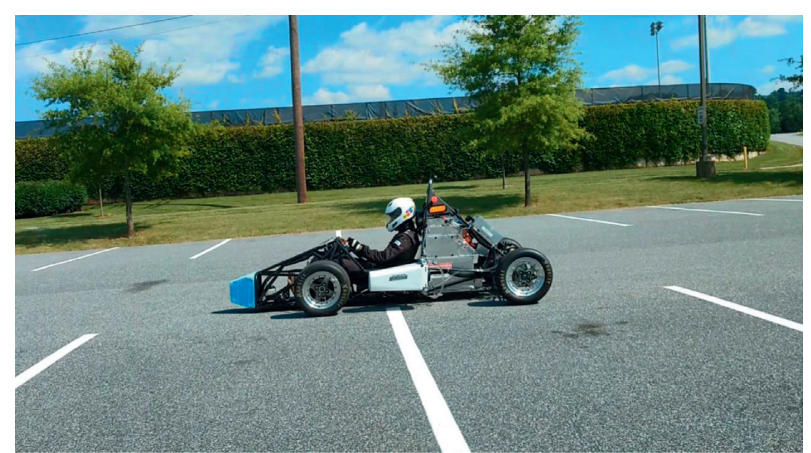

Figure 12: Test driving.

(ii) Describe how the system, component, or process meets desired needs within quantitative constraints

(iii) Describe how the system, component, or process meets desired needs within qualitative constraints

(iv) Describe how the system, component, or process meets desired needs within economic constraints

(v) Demonstrate an understanding of the impact of your engineering solutions in a global context

(vi) Demonstrate an understanding of the impact of your engineering solutions in an economic context

(vii) Demonstrate an understanding of the impact of your engineering solutions in an environmental context

(viii) Demonstrate an understanding of the impact of your engineering solutions in a societal context

The engineering programs use rubrics to assess each of the student outcomes and discuss them in the faculty retreat. The goal of the retreat was to find the strengths and weaknesses of the programs as well as the ways to improve. During the retreat, the faculty discusses the student outcomes at the program level. Figure 13 summarizes the student outcome assessment of this project. To attain a student outcome, $75 \%$ of the students need to exceed or meet that student outcome. It can be seen from Figure 13 that all student outcomes are attained by the students in this project except SO7. Students had some difficulties on critically evaluating information and its sources. The faculty recognized this weakness and devised a plan to emphasize it early in the curriculum.

This project also implemented a peer-to-peer rating and ranking evaluation method. Each student was asked to rate himself/herself and the team members with justifications. The rating ranges from 0 to 8 : consistently went above and beyond, tutored teammates, carried more than his/her fair share of the load (8); consistently did what he/she was supposed to do, very well prepared, and cooperative (7); usually did what he/she was supposed to do, acceptably prepared and cooperative (6); often did what he/she was supposed to do, minimally prepared and cooperative (5); sometimes failed to show up or complete assignments, rarely prepared (4); often failed to show up or complete assignments, rarely prepared (3); consistently failed to show or 


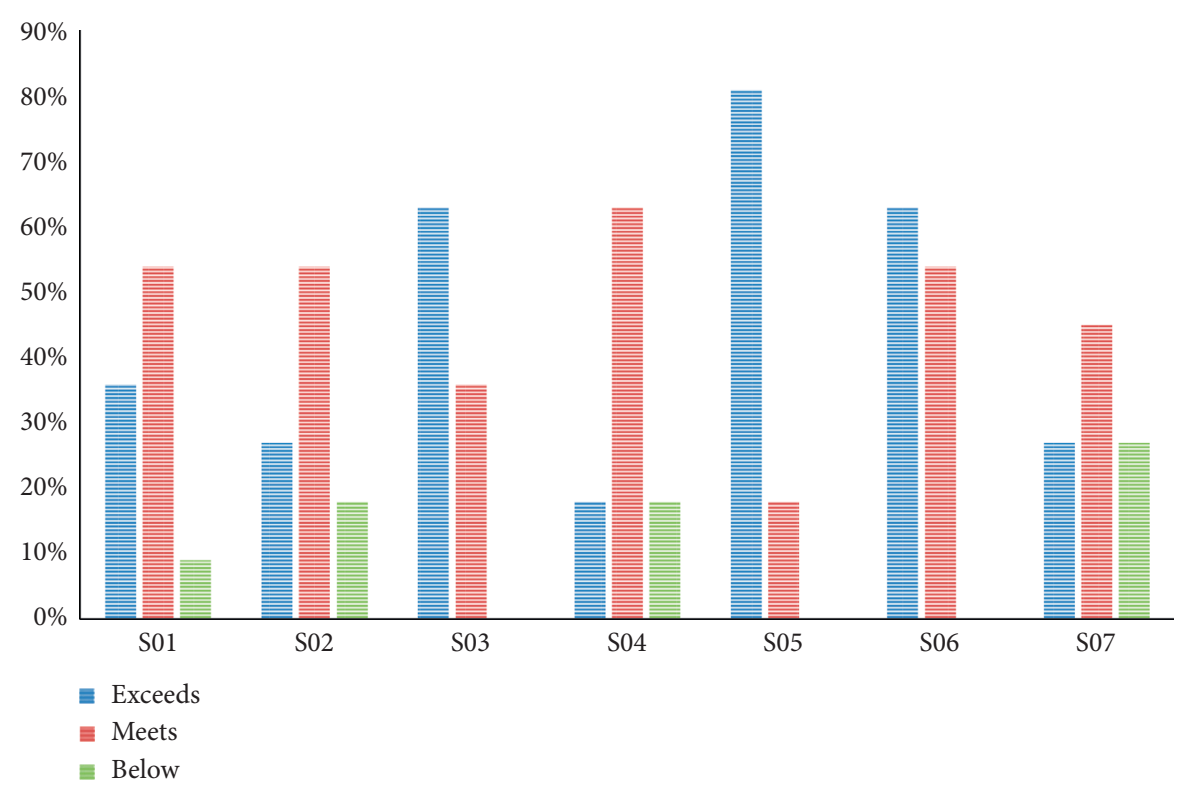

Figure 13: Student outcome assessment results $(n=11)$.

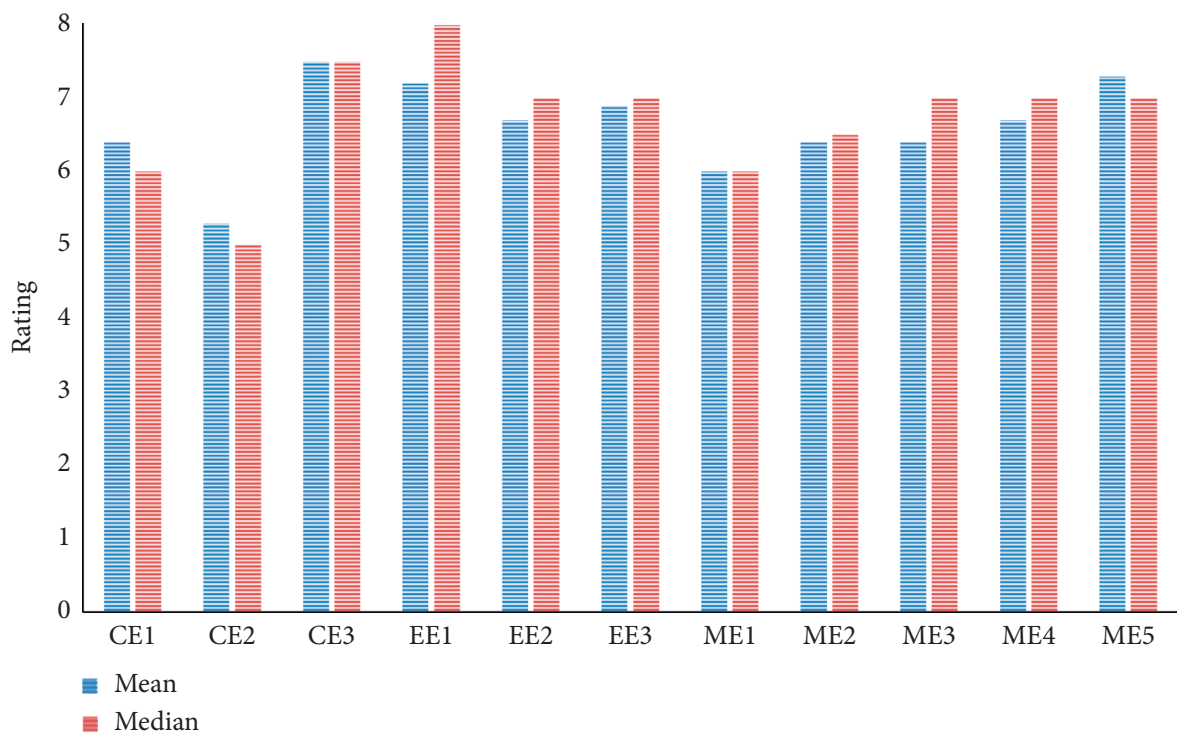

Figure 14: Peer-to-peer rating results.

complete assignments, unprepared (2); practically no participation (1); no participation at all (0). Figure 14 shows that 10 out of 11 students had the mean value of the peer rating 6 or higher and the median follows the mean value very closely. This shows their dedication and team efforts towards the project. Students were also asked to rank each member of their team (including themselves) from 1 (highest) to 11 (lowest) for their combined effort and effectiveness. This is a force ranking system, and no two students can have the same ranking. This response should reflect each individual's dedication to the team and support of its goals, not academic ability. Figure 15 shows where each student stands relative to their team members. This would motivate them to do better in the future towards the team's objectives. Dedicated students were ranked between 1 and 5, seriously engaged student ranks were between 5 and 9 , and if students were not seriously engaged with the project, they were ranked between 9 and 11. This project only had one student who was ranked higher than 9. Results from Figures 14 and 15 correlate well and justify the rating and ranking by the peers. Both rating and ranking peer-to-peer evaluation results concluded that the project was successful in creating a multidisciplinary teamwork environment. Here is a justification for rating 8 and rank 1 from the peer-to-peer assessment form: "solid teammate, extremely hard working $\mathrm{Xxxx}$ dominated the software development of the car, and 


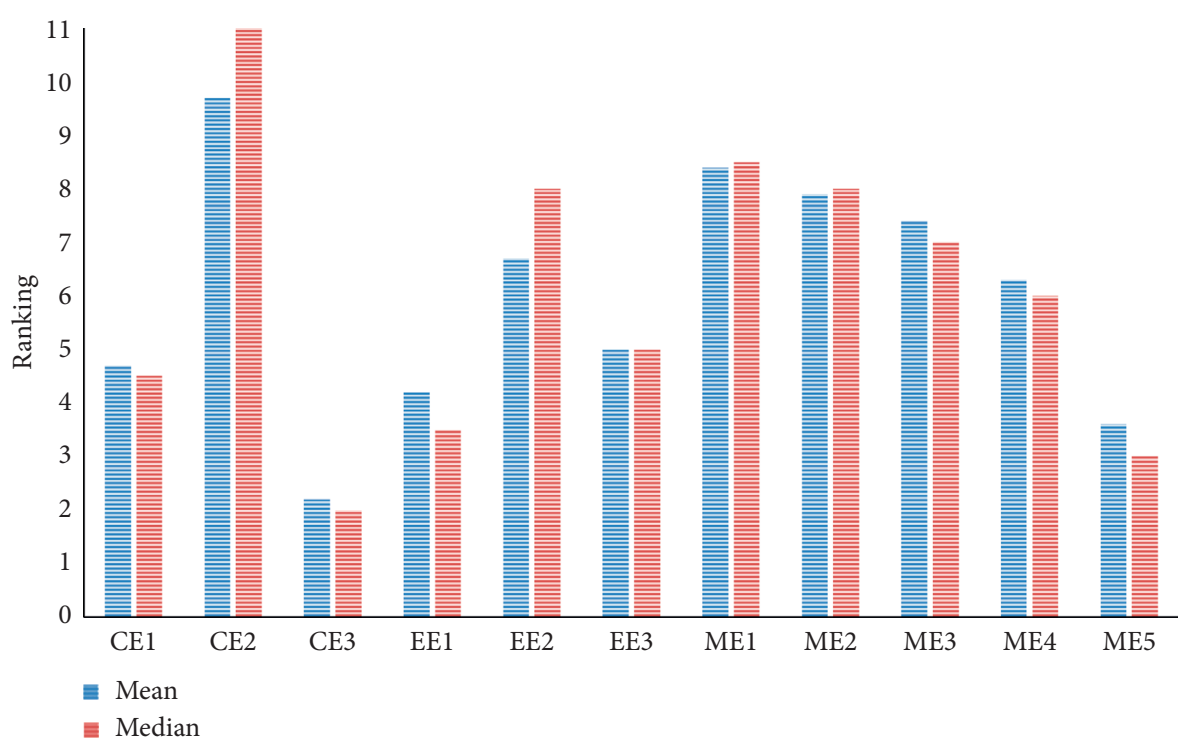

FIGURE 15: Peer-to-peer ranking results.

enabled us to reach important goals such as communicating with the motor controller. He consistently works on Capstone and seems to be aware of nearly all aspects of the car and communicates well with others. It is unbelievable how much he has done especially considering how much he has had to deal with this semester."

ABET student outcome assessment and peer-to-peer rating and ranking data showed that a well thought out multidisciplinary capstone design project can benefit students by preparing them for the real-world engineering practices. This project emulates the real-world experiences by combining computer, electrical, and mechanical engineering students under one project along with the FSAE hybrid vehicle rules. Students realized the importance of the interdisciplinary communication skills, organization skills, teamwork, and research and discovery. More importantly, students used their knowledge in science and engineering to identify, formulate, and solve complex engineering problems with economic, safety, societal, and environmental factors. This project successfully created a bridge between the academia and the real-world engineering practices.

\section{Conclusions}

This paper presented a multidisciplinary capstone design project where students from mechanical, electrical, and computer engineering programs worked together to design, build, and test drive an FSAE electric vehicle. The paper details the management and assessment of student growth and learning in a number of critical ABET skills they will need during their careers. The faculty involvement, management, and assessment of the capstone design project were described in detail throughout this paper. The importance of communication between team members on the project is paramount to the team and project's overall success. This responsibility is placed on the students requiring that each subteam present and discuss their results and concerns in weekly meetings. Not surprisingly, the students learn how to solve complex and open-ended problems through this ongoing process. The faculty members serve in the role of mentor during the presentations allowing the students to independently solve problems and present solutions. This leads to students designing their own experiments to test their ideas and allows them to draw appropriate conclusions for systemlevel integration. Key to this process is how they communicate effectively and recognize ethical and professional responsibilities. The subsystems and the system level integration were validated by laboratory testing and a test drive.

Without question, this was a successful end-to-end capstone design experience for both the students and the faculty. Students are allowed to make mistakes and prompted to self-assess from their experiences. No less important is that the faculty must also perform self-assessment and examine the process as it is and how it might be improved. The presentation of this paper is part of that process. In general, the faculty employed proven techniques using PBL to administer the project. In the process, students were forced to solve many problems to include the typical compromises required to bring a multifaceted project to fruition. ABET student outcome assessment and peer-to-peer rating and ranking data demonstrated a successful integration of multidisciplinary aspects and teamwork in their capstone project. They also show growth by the students that should serve them well in the workforce when dealing with their peers.

\section{Data Availability}

The data used during this study are available from the corresponding author on reasonable request.

\section{Conflicts of Interest}

The authors declare that they have no conflicts of interest. 


\section{References}

[1] L. J. McKenzie, M. S. Trevisan, D. C. Davis, and S. Beyerlein, "Capstone design courses and assessment: a national study," in Proceedings of the American Society of Engineering Education Annual Conference \& Exposition, Salt Lake City, Utah, June 2004.

[2] S. Howe, L. Rosenbauer, and S. Poulos, "The 2015 capstone design survey results: current practices and changes over time," International Journal of Engineering Education, vol. 33, no. 5, pp. 1393-1421, 2017.

[3] ABET, "Criteria for accrediting engineering programs," 20182019, https://www.abet.org/accreditation/accreditation-criteria/ criteria-for-accrediting-engineering-programs-2018-2019/.

[4] R. Bruhn and J. Camp, "Creating corporate world experience in capstone courses," in Proceedings of the 34th Annual ASEE/ IEEE Frontiers in Education, Savannah, GA, USA, June 2004.

[5] J. J. Pembridge and M. C. Paretti, "The current state of capstone design pedagogy," in Proceedings of the American Society in Engineering Education Annual Conference and Exhibition, Louisville, KY, USA, 2010.

[6] A. Kolmos and E. De Graaff, Problem-Based and Project-Based Learning in Engineering Education: Merging Models, A. Johri and B. M. Olds, Eds., Cambridge University Press, Cambridge, England, 2014.

[7] M. V. Manuel, A. F. McKenna, and G. B. Olson, "Hierarchical model for coaching technical design teams," International Journal of Engineering Education, vol. 24, no. 2, pp. 260-265, 2008.

[8] D. T. Rover, "Perspectives on learning in a capstone design course," in Proceedings of the 30th Annual Frontiers in Education Conference, Kansas City, KS, USA, 2000.

[9] R. H. Todd, S. P. Magleby, C. D. Sorensen, B. R. Swan, and D. K. Anthony, "A survey of capstone engineering courses in North America," Journal of Engineering Education, vol. 84, no. 2, pp. 165-174, 1995.

[10] M. S. Trevisan, D. C. Davis, R. W. Crain, D. E. Calkins, and K. L. Gentili, "Developing and assessing statewide competencies for engineering design," Journal of Engineering Education, vol. 87, no. 2, pp. 185-193, 1998.

[11] D. R. Woods, "An evidence-based strategy for problem solving," Journal of Engineering Education, vol. 89, no. 4, pp. 443-459, 2000.

[12] ABET, "Self-study templates," 2019, https:/www.abet.org/ accreditation/accreditation-criteria/self-study-templates/.

[13] J. A. Marin, J. E. J. Armstrong, and J. L. Kays, "Elements of an optimal capstone design experience," Journal of Engineering Education, vol. 88, no. 1, pp. 19-22, 1999.

[14] D. Bocci, D. Fraser, T. Gee, and H. Hoffmann, "Formula hybrid rules," SAE International and the Trustees of Dartmouth College, Hanover, NH, USA, 2018.

[15] W. Mokhtar, P. Duesing, and R. Hildebrand, "Integration of project-based learning (PBL) into mechanical engineering programs," International Journal of Learning, vol. 15, no. 8, 2008.

[16] S. A. Wilkerson, J. Forsyth, and C. M. Korpela, "Project based learning using the robotic operating system (ROS) for undergraduate research applications," in Proceedings of the ASEE Annual Conference \& Exposition, Columbus, OH, USA, 2017.

[17] S. A. Wilkerson, S. A. Gadsden, A. Lee, R. N. Vandemark, E. Hill, and A. D. Gadsden, "Board 64: ROS as an undergraduate project-based learning enabler," in Proceedings of the ASEE Annual Conference \& Exposition, Salt Lake City, UT, USA, July 2018.
[18] S. A. Wilkerson, S. A. Gadsden, J. Cerreta, and M. Al-Shabi, "Drone-based technologies used to assess modern farming practices in undergraduate research with project-based learning," in Proceedings of the ASEE Conference, New York, NY, USA, 2018.

[19] EMRAX, "User's manual for advanced axial flux synchronous motors and generators," August 2018, http://emrax.com/wpcontent/uploads/2017/10/user_manual_for_emrax_motors.pdf.

[20] Unitek, Bamocar D3, UniTek Industrie Elektronik GmbH (c) 2019, January 2019, https://www.unitek-industrie-elektronik.de/ bamocar-d3.

[21] A. Tokosch, D. Hake, K. Meah, and J. Maier, "Design and implementation of a drivetrain for an FSAE electric vehicle," in Proceedings of the IEEE International Conference on Environment and Electrical Engineering and IEEE Industrial and Commercial Power Systems Europe (EEEIC/I\&CPS Europe), Genova, Italy, June 2019.

[22] A. Ulatowski and A. Bazzi, "Combinational-logic based traction inverter fault diagnosis," in Proceedings of the Advanced Power Electron Conference and Expo, Charlotte, NC, USA, March 2015.

[23] A. Ulatowski and A. Bazzi, "A combinational-logic method for electric vehicle drivetrain fault diagnosis," IEEE Transactions on Industry Applications, vol. 52, no. 2, pp. 1796-1807, 2016.

[24] S. A. McInerny and Y. Dai, "Basic vibration signal processing for bearing fault detection," IEEE Transactions on Education, vol. 46, no. 1, pp. 149-156, 2003.

[25] S. Nandi, H. A. Toliyat, and X. Li, "Condition monitoring and fault diagnosis of electrical motors-A review," IEEE Transactions on Energy Conversion, vol. 20, no. 4, pp. 719-729, 2005.

[26] F. Zidani, M. El Hachemi Benbouzid, D. Diallo, and M. S. Nait-Said, "Induction motor stator faults diagnosis by a current Concordia pattern-based fuzzy decision system," IEEE Transactions on Energy Conversion, vol. 18, no. 4, pp. 469-475, 2003.

[27] W. Chen, L. Wang, A. Ulatowski, and A. M. Bazzi, “A fuzzy logic approach for fault diagnosis and recovery in PHEV and EV chargers," in Proceedings of the IEEE Transportation Electrification Conference and Expo, Dearborn, MI, USA, March 2014.

[28] W. Jianfeng, W. Dafang, and X. Jie, "The design of electric motor car's body network based on CAN-bus distributed control," in Proceedings of the Chinese Control and Decision Conference, Guilin, China, 2009.

[29] S. Corrigan, Introduction to the Controller Area Network (CAN), Texas Instrument, Dallas, TX, USA, 2016.

[30] Sparkfun, Teensy 3.6, 2017, https://www.sparkfun.com/ products/14058.

[31] High-Speed CAN Transceiver, "MCP2561/2," Mcrochip Technology Inc., Chandler, AZ, USA, 2013-2014.

[32] G. A. Magallan, C. H. D. Angelo, and G. O. Garcia, "A neighbourhood-electric vehicle development with individual traction on rear wheels," International Journal of Electric and Hybrid Vehicles, vol. 2, no. 2, pp. 115-136, 2009.

[33] J. L. Bossa, G. A. Magallán, C. H. D. Angelo, and G. O. García, "Implementation of a supervisory control system for an electric vehicle," in Proceedings of the 9th IEEE/IAS International Conference on Industry Applications, Sao Paulo, Brazil, November 2010.

[34] P. Pedret, "Control systems for high performance electric cars," in Proceedings of the World Electric Vehicle Symposium and Exhibition, Barcelona, Spain, 2013. 
[35] D. C. Jayasuriya, M. Rankin, T. Jones, J. d. Hoog, D. Thomas, and T. Mareels, "Modeling and validation of an unbalanced LV network using Smart Meter and SCADA inputs," in Proceedings of the IEEE 2013 Tencon-Spring, Sydney, NSW, Australia, April 2013.

[36] T. K. Lee, Y. Kim, A. Stefanopoulou, and Z. S. Filipi, "Hybrid electric vehicle supervisory control design reflecting estimated lithium-ion battery electrochemical Dynamics," in Proceedings of the American Control Conference, San Francisco, CA, USA, 2011.

[37] V. M. Leite, J. G. Palma, and F. H. d. Oliveira, "Definition of a computing independent model and rules for transformation focused on the model-view-controller architecture," International Journal of Computer, Electrical, Automation, Control and Information Engineering, vol. 11, no. 2, 2017.

[38] D. Zissis, E. K. Xidias, and D. Lekkas, "A cloud based architecture capable of perceiving and predicting multiple vessel behaviour," Applied Soft Computing, vol. 35, pp. 652-661, 2015.

[39] I. Kravets, "A new generation ecosystem for embedded development," 2014-2019, http://platformio.org/.

[40] Microsoft, Visual Studio Code, 2019, https://code.visualstudio. $\mathrm{com} /$.

[41] Y. Lindsjørn, D. I. Sjøberg, T. Dingsøyr, G. R. Bergersen, and T. Dybå, "Teamwork quality and project success in software development: a survey of agile development teams," Journal of Systems and Software, vol. 122, pp. 274-286, 2016.

[42] K. Rolland, B. Fitzgerald, T. Dingsoyr, and K. J. Stol, "Problematizing agile in the large: alternative assumptions for large-scale Agile development," in Proceedings of the 37th International Conference on Information Systems, Dublin, Ireland, December 2016.

[43] Orion BMS, "Ewert energy systems, Inc.," 2019, http://www. orionbms.com/. 